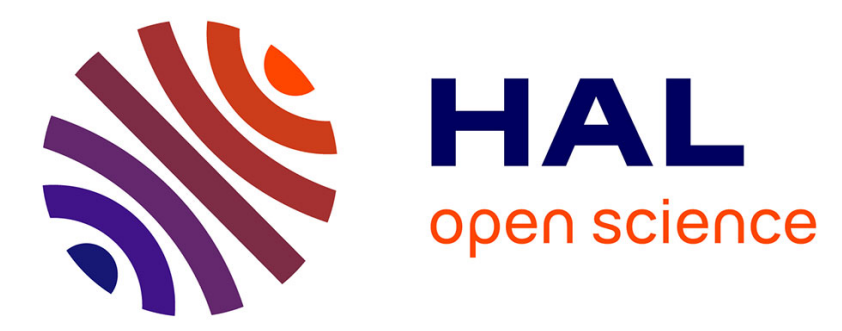

\title{
Dissociation kinetics of Mn2+ complexes of NOTA and DOTA
}

Bohuslav Drahoš, Vojtěch Kubíček, Celia Bonnet, Petr Hermann, Ivan Lukeš, Éva Tóth

\section{- To cite this version:}

Bohuslav Drahoš, Vojtěch Kubíček, Celia Bonnet, Petr Hermann, Ivan Lukeš, et al.. Dissociation kinetics of Mn2+ complexes of NOTA and DOTA. Dalton Transactions, 2011, 40 (9), pp.1945. 10.1039/c0dt01328e . hal-00614890

\section{HAL Id: hal-00614890 \\ https://hal.science/hal-00614890}

Submitted on 29 Sep 2021

HAL is a multi-disciplinary open access archive for the deposit and dissemination of scientific research documents, whether they are published or not. The documents may come from teaching and research institutions in France or abroad, or from public or private research centers.
L'archive ouverte pluridisciplinaire HAL, est destinée au dépôt et à la diffusion de documents scientifiques de niveau recherche, publiés ou non, émanant des établissements d'enseignement et de recherche français ou étrangers, des laboratoires publics ou privés. 


\title{
Dissociation kinetics of $\mathrm{Mn}^{2+}$ complexes of NOTA and DOTA $\dagger$
}

\author{
Bohuslav Drahoš, ${ }^{\text {ab }}$ Vojtěch Kubíček, ${ }^{a}$ Célia S. Bonnet, ${ }^{b}$ Petr Hermann, ${ }^{a}$ Ivan Lukeš ${ }^{\star a}$ and Éva Tóth ${ }^{* b}$
}

The kinetics of transmetallation of $[\mathrm{Mn}(\text { nota })]^{-}$and $[\mathrm{Mn}(\text { dota })]^{2-}$ was investigated in the presence of $\mathrm{Zn}^{2+}$ (5-50-fold excess) at variable $\mathrm{pH}(3.5-5.6)$ by ${ }^{1} \mathrm{H}$ relaxometry. The dissociation is much faster for $[\mathrm{Mn}(\text { nota })]^{-}$than for $[\mathrm{Mn}(\mathrm{dota})]^{2-}$ under both experimental and physiologically relevant conditions $\left(t_{\frac{1}{2}}=74 \mathrm{~h}\right.$ and $1037 \mathrm{~h}$ for $[\mathrm{Mn}(\text { nota })]^{-}$and $[\mathrm{Mn}(\text { dota })]^{2-}$, respectively, at $\mathrm{pH} 7.4, c\left(\mathrm{Zn}^{2+}\right)=10^{-5} \mathrm{M}$, $\left.25^{\circ} \mathrm{C}\right)$. The dissociation of the complexes proceeds mainly via spontaneous $\left([\mathrm{Mn}(\mathrm{nota})]^{-} k_{0}=(2.6 \pm 0.5)\right.$ $\left.\times 10^{-6} \mathrm{~s}^{-1} ;[\mathrm{Mn}(\text { dota })]^{2-} k_{0}=(1.8 \pm 0.6) \times 10^{-7} \mathrm{~s}^{-1}\right)$ and proton-assisted pathways $\left([\mathrm{Mn}(\text { nota })]^{-} k_{1}=(7.8 \pm\right.$ $\left.0.1) \times 10^{-1} \mathrm{M}^{-1} \mathrm{~s}^{-1} ;[\mathrm{Mn}(\text { dota })]^{2-} k_{1}=(4.0 \pm 0.6) \times 10^{-2} \mathrm{M}^{-1} \mathrm{~s}^{-1}, k_{2}=(1.6 \pm 0.1) \times 10^{3} \mathrm{M}^{-2} \mathrm{~s}^{-1}\right)$. The observed suppression of the reaction rates with increasing $\mathrm{Zn}^{2+}$ concentration is explained by the formation of a dinuclear $\mathrm{Mn}^{2+}-\mathrm{L}-\mathrm{Zn}^{2+}$ complex which is about 20-times more stable for [Mn(dota) $]^{2-}$ than for $[\mathrm{Mn}(\text { nota })]^{-}\left(K_{\mathrm{MnLZn}}=68\right.$ and 3.6, respectively), and which dissociates very slowly $\left(k_{3}\right.$ $\left.\sim 10^{-5} \mathrm{M}^{-1} \mathrm{~s}^{-1}\right)$. These data provide the first experimental proof that not all $\mathrm{Mn}^{2+}$ complexes are kinetically labile. The absence of coordinated water makes both $[\mathrm{Mn}(\text { nota })]^{-}$and $[\mathrm{Mn}(\mathrm{dota})]^{2-}$ complexes inefficient for MRI applications. Nevertheless, the higher kinetic inertness of [Mn(dota) ${ }^{2-}$ indicates a promising direction in designing ligands for $\mathrm{Mn}^{2+}$ complexation.

\section{Introduction}

Chelates of paramagnetic metal ions $\left(\mathrm{Gd}^{3+}, \mathrm{Mn}^{2+}, \mathrm{Fe}^{3+}\right)$ are widely applied and studied as contrast agents (CAs) in magnetic resonance imaging (MRI). ${ }^{1-5}$ For the safe use of a metal complex as MRI CA, high thermodynamic stability (high complex stability constant) and kinetic inertness (slow complex dissociation under physiological conditions) are required to prevent the in vivo release of free ligand and free metal ion as both are very toxic. ${ }^{6,7}$ The kinetic inertness in plasma is related primarily to the displacement of the paramagnetic metal from the complex by endogenous metal ions. The complex dissociation can proceed via metalassisted (direct attack of the competing ion on the complex) or proton-assisted pathways. ${ }^{7,8}$ In the case of the widely studied $\mathrm{Gd}^{3+}$ complexes, the dissociation kinetics is usually investigated either in strongly acidic media (for DOTA derivatives) ${ }^{9-12}$ or in the presence of a high excess of a competing metal ion (mostly for DTPA derivatives). ${ }^{13-17}$ These conditions are far from the physiological ones, however, they allow to determine the rates

${ }^{a}$ Department of Inorganic Chemistry, Faculty of Science, Universita Karlova (Charles University), Hlavova, 2030, 12843 Prague 2, Czech Republic. E-mail: lukes@natur.cuni.cz; Fax: +420-22195-1253; Tel: +420-221951263

${ }^{b}$ Centre de Biophysique Moléculaire, CNRS, rue Charles Sadron, 45071, Orléans, France. E-mail: eva.jakabtoth@cnrs-orleans.fr; Fax: +33 238257807; Tel: +33 238257625 of dissociation which would be too long to investigate under physiological conditions. Further, it allows to compare the kinetic inertness of different complexes studied in a similar way.

Most clinical contrast agents are based on $\mathrm{Gd}^{3+}$. However, there is a great interest in chelates of other paramagnetic metal ions as efficient relaxation agents for MRI applications. Complexes of the divalent manganese ion, possessing five unpaired electrons and slow electron spin relaxation, are appealing alternatives. ${ }^{18-24}$ However, the chemistry of $\mathrm{Mn}^{2+}$ complexes with polydentate ligands which might be suitable for MRI is little developed in comparison to the chemistry of the $\mathrm{Gd}^{3+}$ analogues. In particular, the kinetic aspects of $\mathrm{Mn}^{2+}$ complexes are essentially unexplored. The lack of ligand-field stabilization in a high-spin $\mathrm{d}^{5}$ electron configuration and the lower positive charge make $\mathrm{Mn}^{2+}$ complexes thermodynamically less stable than other transition metal ions or $\mathrm{Gd}^{3+}$ analogues. In addition, even the $\mathrm{Mn}^{2+}$ complexes endowed with a high thermodynamic stability, e.g. $[\mathrm{Mn}(\mathrm{dtpa})]^{3-}$, were found to be kinetically labile and did not prevent the accumulation of $\mathrm{Mn}^{2+}$ in the brain after administration of the agent. ${ }^{25}$

It is evident that the stability criteria for the use of $\mathrm{Mn}^{2+}$ complexes can be considered less strict as manganese is an endogenous element. The only $\mathrm{Mn}^{2+}$-based contrast agent in clinical use, $[\mathrm{Mn}(\mathrm{dpdp})]^{4-}$, has no inner-sphere water molecule and, thus, it is a weak relaxation agent (only outer-sphere relaxation effect). In vivo, it undergoes dissociation and the observed in vivo relaxation effect is mainly related to the released free hydrated $\mathrm{Mn}^{2+}$. The role of the ligand is to ensure a slower release of free $\mathrm{Mn}^{2+}$ and, thus, to prevent toxicity ( $\mathrm{dpdp}^{6-}=N, N^{\prime}$-dipyridoxylethylenediamine$N, N^{\prime}$-diacetate-5, $5^{\prime}$-bis-(phosphate)) ${ }^{20,26}$ 
<smiles>O=C(O)CN1CCN(CC(=O)O)CCN(CC(=O)O)CC1</smiles>

NOTA

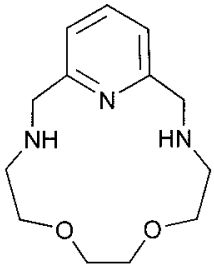

$15-\mathrm{pyN}_{2} \mathrm{O}_{2}$<smiles>O=C(O)CN1CCN(CC(=O)O)CCN(CC(=O)O)CCN(CC(=O)O)CC1</smiles>

DOTA<smiles>NC(=O)CN1CCN(CC(N)=O)CCN(CC(N)=O)CCN(CC(N)=O)CC1</smiles>

DOTAM

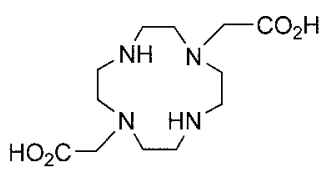

1,7-DO2A<smiles>O=C(O)CN(CCN(CC(=O)O)CC(=O)O)CCN(CC(=O)O)CC(=O)O</smiles>

DTPA

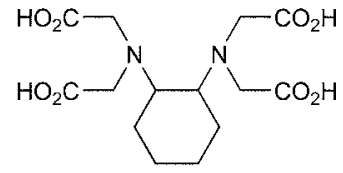

CyDTA<smiles>O=C(O)CN1CCCN(CC(=O)O)N(CC(=O)O)CCN(CC(=O)O)CC1</smiles>

TRITA

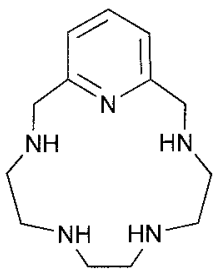

$15-\mathrm{pyN}_{4}$<smiles>O=C(O)CN1CCCN(CC(=O)O)CCN(CC(=O)O)CCC1</smiles>

TETA

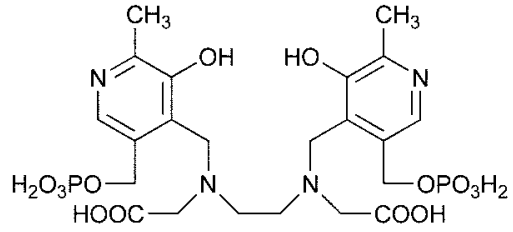

DPDP

Chart 1 Structure of the ligands studied or discussed in the text.

To the best of our knowledge, there has been only one report on the dissociation of a $\mathrm{Mn}^{2+}$ complex. ${ }^{19}$ This study, involving the 15 -membered pyridine-based macrocycles $15-\mathrm{pyN}_{4}$ and $15-$ py $\mathrm{N}_{2} \mathrm{O}_{2}$ (Chart 1), revealed the importance of the proton-assisted dissociation even at physiological $\mathrm{pH}$. More extensive knowledge of the kinetic behavior of $\mathrm{Mn}^{2+}$ complexes with various types of ligands could be very helpful in the design of suitable $\mathrm{Mn}^{2+}$-based MRI contrast agents.

In this perspective, here we report a dissociation kinetic study of $\mathrm{Mn}^{2+}$ complexes formed with two common polydentate macrocyclic ligands, NOTA and DOTA (Chart 1). None of the complexes is applicable as CA for MRI, as they do not contain any water molecule directly coordinated to the metal ion. ${ }^{23,27-31}$ Nevertheless, the results might give insight into the factors determining kinetic inertness of $\mathrm{Mn}^{2+}$ complexes in general and, therefore, contribute to the choice of the ligand skeleton most suitable for MRI purposes. These data represent the first dissociation kinetic study of $\mathrm{Mn}^{2+}$ chelates formed with this important class of ligands whose complexes with a range of other metal ions are widely employed today in molecular imaging. ${ }^{2,3}$

\section{Experimental}

The ligands NOTA and DOTA were purchased from CheMatech and used as received. Deionized water was used for preparation of all solutions. Solutions of the $\mathrm{Mn}^{2+}$ complexes were prepared by mixing $\mathrm{MnCl}_{2}(410 \mathrm{mM})$ and NOTA $(50.1 \mathrm{mM})$ or DOTA (46.9 $\mathrm{mM}$ ) solutions in $\mathrm{Mn}: \mathrm{L}=1: 1.05$ molar ratio and the $\mathrm{pH}$ was adjusted to 8.0 with a diluted $\mathrm{NaOH}$ solution. The transmetallation of $[\mathrm{Mn}(\text { nota) })]^{-}$and $[\mathrm{Mn}(\text { dota })]^{2-}$ with $\mathrm{Zn}^{2+}$ was followed by monitoring the relaxivity at $0.5 \mathrm{MHz}$ on a Stelar
SMARTracer fast field-cycling relaxometer $\left(c_{\mathrm{Mn}}=1 \mathrm{mM}, 0.02 \mathrm{M}\right.$ $N$-methylpiperazine buffer) in the $\mathrm{pH}$ range 3.5-5.6 and in the presence of $5,10,20,30$ and 50 -fold excess of the exchanging $\mathrm{Zn}^{2+}$ at $25{ }^{\circ} \mathrm{C}$ and $0.1 \mathrm{M} \mathrm{KCl}$. The relaxivity, $r_{1}$, is defined as the paramagnetic enhancement of the longitudinal water proton relaxation rate referred to $1 \mathrm{mM}$ concentration of $\mathrm{Mn}^{2+}$. Each sample was prepared by mixing $1 \mathrm{ml}$ of a buffered $\mathrm{ZnCl}_{2}$ solution of a given concentration with an appropriate amount of [Mn(nota) $]^{-}$ $\left(c_{\mathrm{Mn}}=41.6 \mathrm{mM}\right)$ or $[\mathrm{Mn}(\mathrm{dota})]^{2-}\left(c_{\mathrm{Mn}}=39.6 \mathrm{mM}\right)$ stock solution in a $10-\mathrm{mm}$ NMR tube. The experiment time varied according to the $\mathrm{pH}$ and corresponded to at least four reaction half-times (e.g. for $\left[\mathrm{Mn}(\text { nota) }]^{-}\right.$at $c_{\mathrm{Zn+}}=50 \mathrm{mM}$ and $\mathrm{pH} 3.5-5.6$, the $t_{\frac{1}{2}}$ varied between 1-52 h). Because of the long duration of the experiments, the samples were stored in a thermostat at $25.0{ }^{\circ} \mathrm{C}$ between the relaxivity measurements. The $\mathrm{pH}$ was measured after each experiment. Parallel control measurements confirmed that the $\mathrm{pH}$ was stable during the experiment. The analysis of the experimental data was performed by the Micromath Scientist program (version 2.0, Salt Lake City, UT) using a least-square fitting procedure ${ }^{32}$ with a weighting factor of $1 / y$.

Protonation constants of NOTA and protonation and stability constants of $[\mathrm{Mn}(\text { nota })]^{-}$were determined by potentiometric titrations. They were carried out in thermostated vessel at $25^{\circ} \mathrm{C}$ and constant ionic strength $0.1 \mathrm{M}\left(\mathrm{NMe}_{4}\right) \mathrm{Cl}$ using PHM $240 \mathrm{pH}-$ meter, a 2-ml ABU 901 automatic piston burette and a GK 2401B combined electrode (all Radiometer, Denmark). Inert atmosphere was provided by a constant passage of argon saturated with the solvent vapor. The initial volume in the titration cell was $5 \mathrm{ml}$ and the concentration of the ligand was about $0.004 \mathrm{M}$. Four parallel titrations were carried out for an $\mathrm{L}: \mathrm{Mn}$ ratio of $1: 1$, with each titration consisting of $40-50$ points. The titrations were run in 
the $-\log \left[\mathrm{H}^{+}\right]$range of $1.9-12.0$ with an extra $\mathrm{HCl}$ added to the starting solution and using $\left(\mathrm{NMe}_{4}\right) \mathrm{OH}$ solution $(\sim 0.2 \mathrm{M})$ as a base. All equilibria were established quickly. For calculations, the OPIUM software package was used. ${ }^{33}$ The value of $\mathrm{p} K_{\mathrm{w}}$ was 13.81 . The stability constants of the $\mathrm{Mn}^{2+}-\mathrm{OH}^{-}$systems were taken from literature. ${ }^{34}$ For more details about potentiometric titrations, see previous papers. ${ }^{35}$ In the followings, $\mathrm{pH}$ means $-\log \left[\mathrm{H}^{+}\right]$and all the equilibrium constants are concentration constants.

The ${ }^{1} \mathrm{H}$ NMR titration for the determination of the highest protonation constant ( $\mathrm{pH}$ range 10.1-13.8, about 15 points) was carried out under conditions close to the potentiometric titrations (no control of ionic strength, $25.0{ }^{\circ} \mathrm{C}$, ligand concentration of about $0.004 \mathrm{M}$ ). A coaxial capillary tube with $\mathrm{D}_{2} \mathrm{O}$ and $t-\mathrm{BuOH}$ was used for the lock and referencing. Protonation constants were calculated with OPIUM ${ }^{33}$ from the dependence of $\delta_{\mathrm{H}}$ of the $\mathrm{CH}_{2}$ groups on $-\log \left[\mathrm{H}^{+}\right]$.

\section{Results}

In order to describe the dissociation kinetics of the [Mn(nota)] and $[\mathrm{Mn}(\mathrm{dota})]^{2-}$ complexes in a similar way as it is commonly done for $\mathrm{Gd}^{3+}$ chelates, we investigated the metal exchange reaction with the diamagnetic $\mathrm{Zn}^{2+}$ at variable $\mathrm{pH}$ via monitoring the release of free $\mathrm{Mn}^{2+}$ by relaxometric measurements. At the low magnetic field employed, there is a large difference in the relaxivity of the complex having no inner-sphere water molecule and, thus, possessing only an outer-sphere contribution to the relaxivity, ${ }^{27}$ and the free $\left[\mathrm{Mn}\left(\mathrm{H}_{2} \mathrm{O}\right)_{6}\right]^{2+}$ having six water molecules directly coordinated to the metal ion and endowed with a strong innersphere relaxivity contribution. In the presence of an excess of the exchanging $\mathrm{Zn}^{2+}$ ion, the rate of the reactions can be expressed as shown in eqn (1), where $k_{\text {obs }}$ is the pseudo-first-order rate constant, and $[\mathrm{MnL}]_{\text {tot }}$ is the total concentration of the complex.

$$
-\frac{d[\mathrm{MnL}]_{\mathrm{tot}}}{d t}=k_{\mathrm{obs}} \times[\mathrm{MnL}]_{\mathrm{tot}}
$$

The observed dissociation rate constants $\left(k_{\mathrm{obs}}\right)$ in the $\mathrm{pH}$ range 3.5-5.6 and in the presence of 5-50-fold excess of $\mathrm{Zn}^{2+}$ are shown in Fig. 1 and 2 and the experimental data are given in ESI (Tables $\mathrm{S} 1-\mathrm{S} 2) \cdot \dagger$

For both complexes, the $k_{\mathrm{obs}}$ values strongly increase with increasing acid concentration at all concentrations of the exchanging metal ion. On the other hand, the overall dissociation rate decreases with increasing $\mathrm{Zn}^{2+}$ concentration. The influence of the increasing concentration of $\mathrm{Zn}^{2+}$ ions is less important for $\mathrm{pHs}$ close to neutral, while it becomes more visible with decreasing $\mathrm{pH}$. This trend is similar to that reported for several $\mathrm{Gd}^{3+}$ chelates. ${ }^{17} \mathrm{It}$ is related to the formation of dinuclear $\mathrm{Mn}^{2+}-$ $\mathrm{L}-\mathrm{Zn}^{2+}$ species which dissociate more slowly than the protonated $\mathrm{MnH}_{i} \mathrm{~L}$ species. This effect, reducing the overall dissociation rate, becomes more obvious at lower $\mathrm{pH}$ with a higher abundance of the protonated species. For the $\mathrm{Mn}^{2+}-\mathrm{NOTA}$ system, the thermodynamic stability constant was previously determined from relaxivity measurements ${ }^{36}$ or by polarography ${ }^{37}$ without indication of protonated species. Here we have investigated this system by potentiometric measurements that revealed the presence of a protonated complex with $\log K_{\mathrm{MnHL}}=2.87$ (Table 1, for details see ESI Table S3†). Analogously, protonated species have been
Table 1 Stepwise protonation constants $\left(\log K_{\mathrm{HiL}}\right)^{a}$ of NOTA and DOTA and stability constants $\left(\log K_{\mathrm{MHiL}}\right)^{b}$ of their complexes with $\mathrm{Mn}^{2+}, \mathrm{Gd}^{3+}$ and $\mathrm{Zn}^{2+}\left(25^{\circ} \mathrm{C}, I=0.1 \mathrm{M}\right)$

\begin{tabular}{lllllll}
\hline Constant $^{a, b}$ & NOTA & \multicolumn{5}{c}{ DOTA } \\
\hline $\log K_{\mathrm{HL}}$ & $13.17^{c}$ & & \multicolumn{3}{c}{$11.74^{d}$} \\
$\log K_{\mathrm{H} 2 \mathrm{~L}}$ & 5.74 & & \multicolumn{3}{c}{$9.67^{d}$} & \\
$\log K_{\mathrm{H} 3 \mathrm{~L}}$ & 3.22 & & & $4.68^{d}$ & & \\
$\log K_{\mathrm{H} 4 \mathrm{~L}}$ & 1.96 & & & $4.11^{d}$ & & \\
$\log K_{\mathrm{H} \mathrm{L} \mathrm{L}}$ & - & & & $2.37^{d}$ & & \\
& $\mathrm{Mn}^{2+}$ & $\mathrm{Gd}^{3+}$ & $\mathrm{Zn}^{2+}$ & $\mathrm{Mn}^{2+}$ & $\mathrm{Gd}^{3+}$ & $\mathrm{Zn}^{2+}$ \\
$\log K_{\mathrm{ML}}$ & $16.30,14.9^{e}, 14.3^{f}$ & $13.7^{g}$ & $18.3^{g}$ & $19.89^{h}$ & $24.67^{d}$ & $20.8^{g}$ \\
$\log K_{\mathrm{MHL}}$ & 2.87 & $3.6^{g}$ & - & $4.26^{h}$ & - & $4.24^{g}$ \\
$\log K_{\mathrm{MH} 2 \mathrm{~L}}$ & - & - & - & $2.99^{h}$ & - & $3.51^{g}$
\end{tabular}

${ }^{a}$ Defined as $K_{\mathrm{HiL}}=\left[\mathrm{H}_{i} \mathrm{~L}\right] /\left[\mathrm{H}^{+}\right] \times\left[\mathrm{H}_{i-1} \mathrm{~L}\right]$ for $i=1-5^{b} K_{\mathrm{ML}}=[\mathrm{ML}] /[\mathrm{L}] \times[\mathrm{M}]$; $K_{\mathrm{MHiL}}=\left[\mathrm{MH}_{i} \mathrm{~L}\right] /\left[\mathrm{MH}_{i-1} \mathrm{~L}\right] \times\left[\mathrm{H}^{+}\right]$for $i=1,2^{c}$ determined by ${ }^{1} \mathrm{H}$ NMR titration (for details see ESI Table S3, Fig. S3†) ${ }^{d}$ ref. $39^{e}$ ref. $36^{f}$ ref. 37 ${ }^{g}$ ref. $38^{h}$ ref. 30
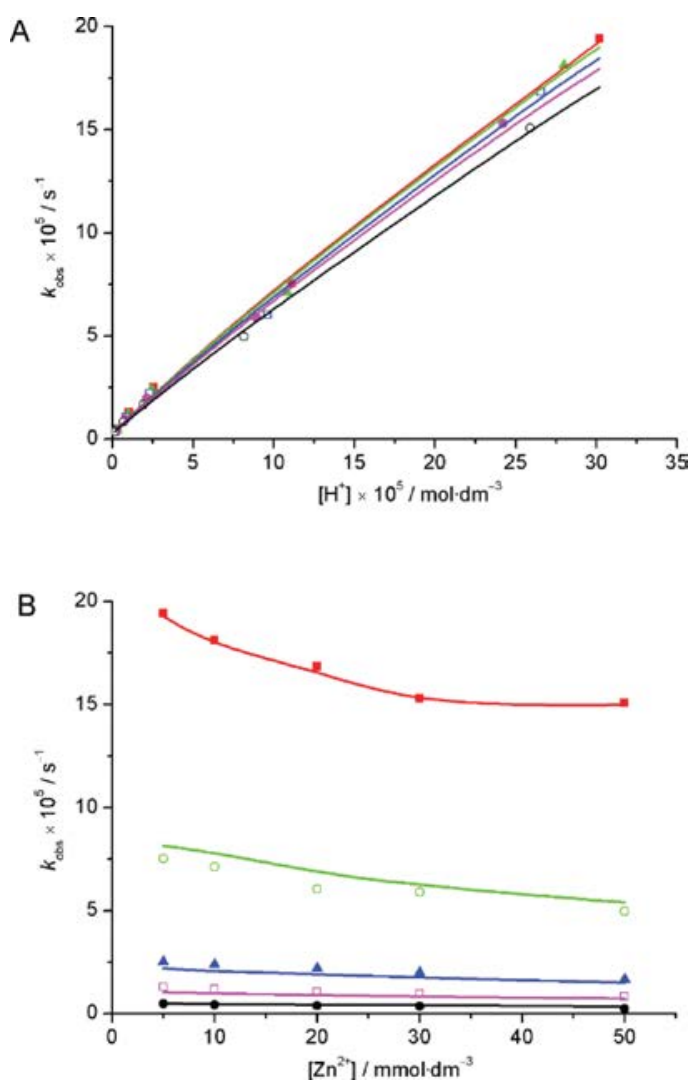

Fig. 1 (a) Dependence of the observed dissociation rate constants for [Mn(nota)]- on proton concentration at $\mathrm{Zn}^{2+}$ concentrations of $5 \mathrm{mM}$ $(\curvearrowleft), 10 \mathrm{mM}(\Delta), 20 \mathrm{mM}(\square), 30 \mathrm{mM}(\bullet)$ and $50 \mathrm{mM}(\odot)$. (b) Dependence of the observed dissociation rate constants for [Mn(nota) $]^{-}$on $\mathrm{Zn}^{2+}$ concentration. $\mathrm{pH}$ readings from the bottom are 5.6, 5.0, 4.6, 4.0 and 3.5. Parts (a) and (b) are different representations of the same experimental data. The lines correspond to the best fit with the parameters given in Table 2.

found in other $\mathrm{M}^{2+}$-NOTA systems (for $\mathrm{Mg}^{2+} \log K_{\mathrm{MHL}}=4.6$, for $\mathrm{Ca}^{2+} \log K_{\mathrm{MHL}}=5.1$ and for $\left.\mathrm{Cu}^{2+} \log K_{\mathrm{MHL}}=2.7\right){ }^{38}$

For $[\mathrm{Mn}(\mathrm{dota})]^{2-}$, two protonated species are known based on potentiometry $^{30}\left(\log K_{\mathrm{MHL}}=4.26, \log K_{\mathrm{MH} 2 \mathrm{~L}}=2.99\right.$; Table 1$)$ and, recently, the X-ray structure of the diprotonated complex with two protonated, uncoordinated acetate arms was also published. ${ }^{31}$ 

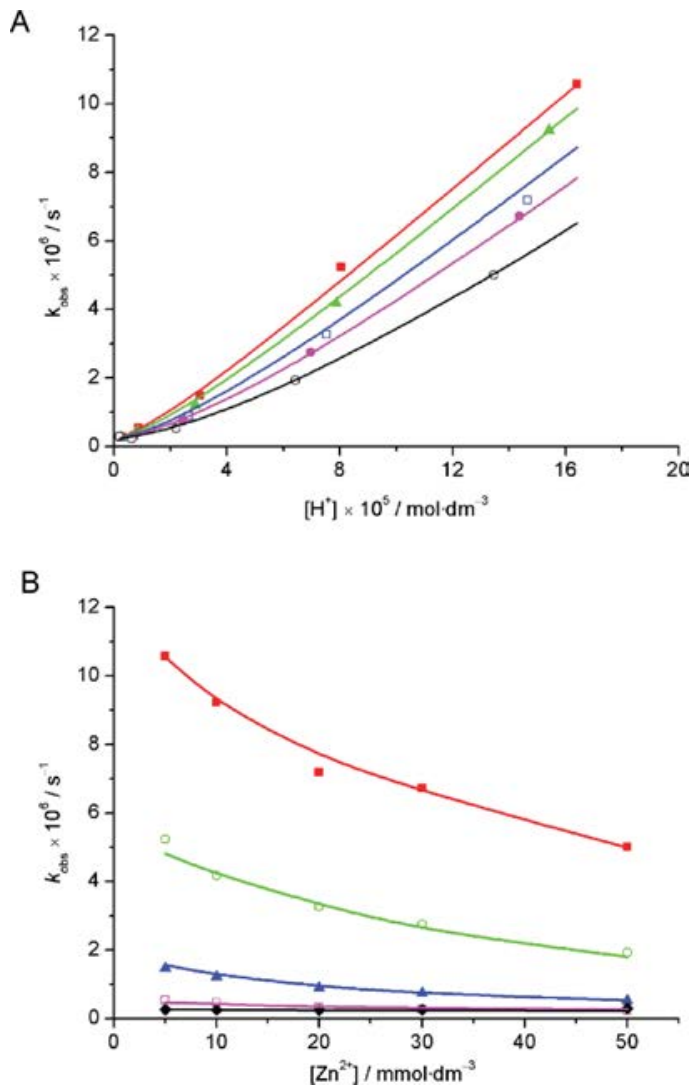

Fig. 2 (a) Dependence of the observed dissociation rate constants for $[\mathrm{Mn}(\text { dota })]^{2-}$ on proton concentration at $\mathrm{Zn}^{2+}$ concentrations of $5 \mathrm{mM}(\square)$, $10 \mathrm{mM}(\triangle), 20 \mathrm{mM}(\square), 30 \mathrm{mM}(\bullet)$ and $50 \mathrm{mM}(\odot)$. (b) Dependence of the observed dissociation rate constants for $[\mathrm{Mn}(\text { dota })]^{2-}$ on $\mathrm{Zn}^{2+}$ concentration. $\mathrm{pH}$ readings from the bottom are 5.6, 5.1, 4.6, 4.1 and 3.8. Parts (a) and (b) are different representations of the same experimental data. The lines correspond to the best fit with the parameters given in Table 2 .

According to the distribution diagrams (see ESI, Fig. S1 and $\mathrm{S} 2 \dagger)$, in the $\mathrm{Mn}^{2+}-\mathrm{NOTA}$ system the non-protonated and the monoprotonated complex, whereas in the $\mathrm{Mn}^{2+}$-DOTA system the non-, mono- and diprotonated species are present in solution under the conditions of the kinetic experiments, and these need to be taken into account to describe the overall dissociation rate. In accordance with this, the experimentally observed dependence on the proton concentration of the rate constants is indeed different for $[\mathrm{Mn}(\text { nota })]^{-}$and $[\mathrm{Mn}(\text { dota })]^{2-}$ (Fig. 1a and 2a).

By taking into account the proton- and metal-assisted pathways and the presence of the differently protonated species, the overall dissociation can be illustrated as shown on Scheme 1 .

By considering the dissociation pathways in Scheme 1, eqn (2) can be derived for the reaction rate:

$$
\begin{aligned}
& -\frac{d[\mathrm{MnL}]_{\mathrm{tot}}}{d t}=k_{\mathrm{MnL}}[\mathrm{MnL}]+k_{\mathrm{MnLZn}}[\mathrm{MnLZn}]+k_{\mathrm{MnHL}}[\mathrm{MnHL}] \\
& +{ }^{\mathrm{H}} k_{\mathrm{MnHL}}[\mathrm{MnHL}]\left[\mathrm{H}^{+}\right]+{ }^{\mathrm{Zn}} k_{\mathrm{MnHL}}[\mathrm{MnHL}]\left[\mathrm{Zn}^{2+}\right] \\
& +k_{\mathrm{MnH} 2 \mathrm{~L}}\left[\mathrm{MnH}_{2} \mathrm{~L}\right]+{ }^{\mathrm{Zn}} k_{\mathrm{MnH} 2 \mathrm{~L}}\left[\mathrm{MnH}_{2} \mathrm{~L}\right]\left[\mathrm{Zn}^{2+}\right]+{ }^{\mathrm{H}} k_{\mathrm{MnH} 2 \mathrm{~L}}\left[\mathrm{MnH}_{2} \mathrm{~L}\right]\left[\mathrm{H}^{+}\right]
\end{aligned}
$$

In eqn (2), each term represents a dissociation pathway; ${ }^{\mathrm{H}} k_{\mathrm{MnHL}}[\mathrm{MnHL}]\left[\mathrm{H}^{+}\right]$applies only for $[\mathrm{Mn}(\text { nota })]^{-}$and the last three terms, related to the presence of the diprotonated species, exist only for $[\mathrm{Mn}(\mathrm{dota})]^{2-}$. As the overall $\mathrm{MnL}$ concentration is the sum of the concentrations of the differently protonated species, eqn (3) and (4) can be derived for the pseudo-firstorder rate constants, $k_{\text {obs }}$, of $[\mathrm{Mn}(\text { nota })]^{-}$and $[\mathrm{Mn}(\text { dota })]^{2-}$, respectively; $k_{0}=k_{\mathrm{MnL}}, k_{1}=k_{\mathrm{MnHL}} \cdot K_{\mathrm{MnHL}}, k_{2}=k_{\mathrm{MnH} 2 \mathrm{~L}} \cdot K_{\mathrm{MnHL}} K_{\mathrm{MnH} 2 \mathrm{~L}}$ (for $\left.[\mathrm{Mn}(\text { dota })]^{2-}\right)$ or $k_{2}=K_{\mathrm{MnHL}} \cdot{ }^{\mathrm{H}} k_{\mathrm{MnHL}}\left(\right.$ for $\left.[\mathrm{Mn}(\text { nota })]^{-}\right), k_{3}=$ $k_{\mathrm{MnLZn}} \cdot K_{\mathrm{MnLZn}}, k_{4}={ }^{\mathrm{Zn}} k_{\mathrm{MnHL}} \cdot K_{\mathrm{MnHL}}, k_{5}={ }^{\mathrm{H}} k_{\mathrm{MnH} 2 \mathrm{~L}} \cdot K_{\mathrm{MnHL}} \cdot K_{\mathrm{MnH} 2 \mathrm{~L}}$ and $k_{6}={ }^{\mathrm{Zn}} k_{\mathrm{MnH} 2 \mathrm{~L}} \cdot K_{\mathrm{MnHL}} \cdot K_{\mathrm{MnH} 2 \mathrm{~L}}$.

$$
k_{\mathrm{obs}}=\frac{\boldsymbol{k}_{\mathbf{0}}+\boldsymbol{k}_{1}\left[\mathbf{H}^{+}\right]+k_{2}\left[\mathrm{H}^{+}\right]^{2}+\boldsymbol{k}_{3}\left[\mathbf{Z n}^{2+}\right]+k_{4}\left[\mathrm{H}^{+}\right]\left[\mathrm{Zn}^{2+}\right]}{\mathbf{1}+\boldsymbol{K}_{\mathrm{MnHL}}\left[\mathbf{H}^{+}\right]+\boldsymbol{K}_{\mathrm{MnLZn}}\left[\mathbf{Z n}^{2+}\right]}
$$

$$
\begin{aligned}
& k_{o b s}= \\
& \frac{\boldsymbol{k}_{\mathbf{0}}+\boldsymbol{k}_{\mathbf{1}}\left[\mathbf{H}^{+}\right]+\boldsymbol{k}_{\mathbf{2}}\left[\mathbf{H}^{+}\right]^{2}+\boldsymbol{k}_{3}\left[\mathbf{Z n}^{2+}\right]+k_{4}\left[\mathrm{H}^{+}\right]\left[\mathrm{Zn}^{2+}\right]+k_{5}\left[\mathrm{H}^{+}\right]^{3}+k_{6}\left[\mathrm{H}^{+}\right]^{2}\left[\mathrm{Zn}^{2+}\right]}{\mathbf{1}+\boldsymbol{K}_{\mathrm{MnHL}}\left[\mathbf{H}^{+}\right]+\boldsymbol{K}_{\mathrm{MnH} 2 \mathrm{~L}}\left[\mathbf{H}^{+}\right]^{2}+\boldsymbol{K}_{\mathrm{MnLZn}}\left[\mathbf{Z n}^{2+}\right]}
\end{aligned}
$$

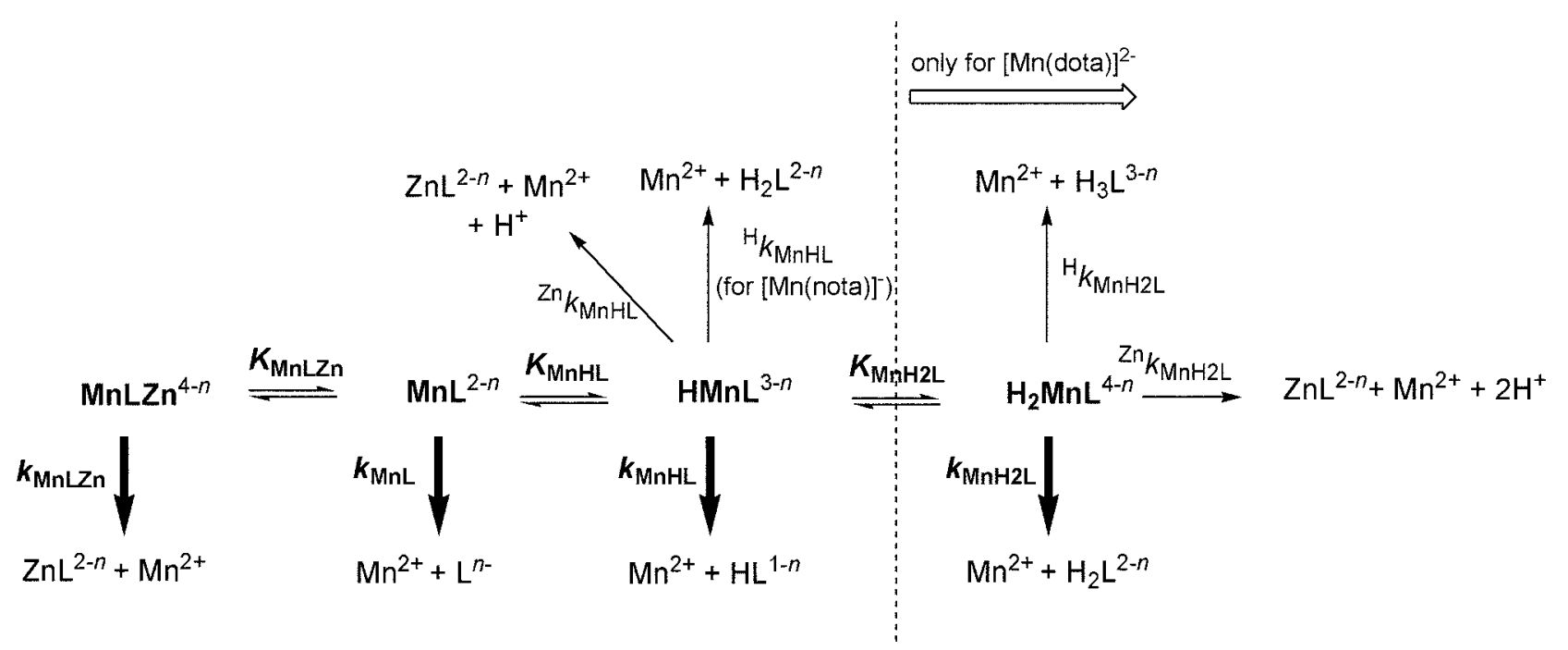

Scheme 1 Possible dissociation pathways for $[\mathrm{Mn}(\text { nota })]^{-}$and $[\mathrm{Mn}(\operatorname{dota})]^{2-}(n=3$ for NOTA and $n=4$ for DOTA). The pathways having a real contribution to the overall dissociation, as indicated by the fit of the observed rate constants, are represented in bold. 
Table 2 Kinetic parameters for the dissociation of $[\mathrm{Mn}(\text { nota })]^{-}$and $[\mathrm{Mn}(\mathrm{dota})]^{2-}$ in comparison to those for $\left[\mathrm{Mn}\left(15-\mathrm{pyN}_{4}\right)\right]^{2+}$ and analogous $\mathrm{Gd} \mathrm{d}^{3+}$ complexes

\begin{tabular}{|c|c|c|c|c|c|c|}
\hline Parameters & {$[\mathrm{Mn}(\text { nota })]^{-}$} & {$[\mathrm{Mn}(\text { dota })]^{2-}$} & {$\left[\mathrm{Mn}\left(15-\mathrm{pyN}_{4}\right)\right]^{2+}$} & {$[\mathrm{Gd}(\text { nota })]^{a}$} & {$[\mathrm{Gd}(\text { dota })]^{-b}$} & {$[\mathrm{Gd}(\mathrm{dtpa})]^{2-c}$} \\
\hline$k_{0} / \mathrm{s}^{-1}$ & $(2.6 \pm 0.5) \times 10^{-6}$ & $(1.8 \pm 0.6) \times 10^{-7}$ & - & $8.3 \times 10^{-6}$ & $5.0 \times 10^{-10}$ & - \\
\hline$k_{1} / \mathrm{M}^{-1} \mathrm{~s}^{-1}$ & $(7.8 \pm 0.1) \times 10^{-1}$ & $(4.0 \pm 0.6) \times 10^{-2}$ & 423 & $2.3 \times 10^{-2}$ & $2.0 \times 10^{-5}$ & 0.58 \\
\hline$k_{2} / \mathrm{M}^{-2} \mathrm{~s}^{-1}$ & $\simeq^{d}$ & $(1.6 \pm 0.1) \times 10^{3}$ & $1.0 \times 10^{7}$ & - & - & $9.7 \times 10^{4}$ \\
\hline$k_{3} / / \mathrm{M}^{-1} \mathrm{~s}^{-1}$ & $(1.1 \pm 0.5) \times 10^{-5}$ & $(1.5 \pm 0.3) \times 10^{-5}$ & - & - & - & $5.6 \times 10^{-2}$ \\
\hline$k_{4} / \mathrm{M}^{-2} \mathrm{~s}^{-1 e}$ & $-^{d}$ & $-^{d}$ & $1.7 \times 10^{4}$ & - & - & - \\
\hline $\log K_{\mathrm{MHL}}$ & $2.87^{f}$ & $4.26^{f}$ & 4.27 & - & - & 2 \\
\hline $\log K_{\mathrm{MH} 2 \mathrm{~L}}$ & $-^{d}$ & $2.99^{f}$ & - & - & - & - \\
\hline$K_{\mathrm{MnLZn}}$ & $3.6 \pm 0.7$ & $68 \pm 6$ & - & - & - & $K_{\mathrm{GdLZn}}=7$ \\
\hline$t_{\frac{1}{2}}\left(\mathrm{pH} \text { 6.0, } c\left(\mathrm{Zn}^{2+}\right)=10^{-3} \mathrm{M}\right)^{g}$ & $58 \mathrm{~h}$ & $868 \mathrm{~h}$ & $26 \mathrm{~min}$ & $23 \mathrm{~h}$ & $3.7 \times 10^{5} \mathrm{~h}$ & $3.4 \mathrm{~h}$ \\
\hline$t_{1}^{2}\left(\mathrm{pH} 6.0, c\left(\mathrm{Zn}^{2+}\right)=10^{-5} \mathrm{M}\right)^{g}$ & $58 \mathrm{~h}$ & $869 \mathrm{~h}$ & $27 \mathrm{~min}$ & $23 \mathrm{~h}$ & $3.7 \times 10^{5} \mathrm{~h}$ & $156 \mathrm{~h}$ \\
\hline$t_{\frac{1}{2}}^{2}\left(\mathrm{pH} 7.4, c\left(\mathrm{Zn}^{2+}\right)=10^{-3} \mathrm{M}\right)^{g}$ & $74 \mathrm{~h}$ & $1024 \mathrm{~h}$ & $11.0 \mathrm{~h}$ & $23 \mathrm{~h}$ & $3.8 \times 10^{5} \mathrm{~h}$ & $3.5 \mathrm{~h}$ \\
\hline$t_{\frac{1}{2}}\left(\mathrm{pH} 7.4, c\left(\mathrm{Zn}^{2+}\right)=10^{-5} \mathrm{M}\right)^{g}$ & $74 \mathrm{~h}$ & $1037 \mathrm{~h}$ & $11.4 \mathrm{~h}$ & $23 \mathrm{~h}$ & $3.8 \times 10^{5} \mathrm{~h}$ & $330 \mathrm{~h}$ \\
\hline
\end{tabular}

${ }^{a}$ Ref. $10^{b} 37^{\circ} \mathrm{C}$, transmetallation with $\mathrm{Eu}^{3+}$, ref. $11 .{ }^{c}$ Ref. $13 .{ }^{d}$ fixed to zero during the fitting procedure ${ }^{e} k_{4}$ describes the zinc-assisted dissociation of the monoprotonated species ${ }^{f}$ fixed to the value obtained from potentiometry ${ }^{g}$ calculated on the basis of the reaction rate constants

The observed rate constants for $[\mathrm{Mn}(\text { nota })]^{-}$and $[\mathrm{Mn}(\mathrm{dota})]^{2-}$ were fitted to eqn (3) or (4), respectively, and the calculated parameters are listed in Table 2. In the fit, the protonation constants were fixed to the values determined by potentiometry (Table 1).

We have considered all possible dissociation pathways but the fit of the $k_{\text {obs }}$ values showed clearly that several terms have no influence and can be neglected. These include the terms related to the proton- and metal-assisted dissociation of the monoprotonated complex [Mn(Hnota)] $\left(k_{2}\right.$ and $\left.k_{4}\right)$, the metal-assisted dissociation of the monoprotonated complex [Mn(Hdota) $]^{-}\left(k_{4}\right)$, and the proton and metal-assisted dissociation of the diprotonated complex [Mn( $\mathrm{H}_{2}$ dota $\left.)\right]\left(k_{5}\right.$ and $\left.k_{6}\right)$. These terms are indicated in normal type in eqn (3) and (4). Including these dissociation pathways in the fitting led to very small or negative values for the corresponding constants with very large errors.

For $[\mathrm{Mn}(\text { nota })]^{-}$, we could calculate the rate constants $k_{0}$ and $k_{1}$ corresponding to the spontaneous dissociation of the nonprotonated and the protonated complexes as well as a low stability constant for the dinuclear complex, $K_{\mathrm{MnLZn}}=3.6$, which dissociates with a small rate constant $k_{3}$ (Table 2, Scheme 1). These results correspond to a close-to-linear dependency of $k_{\text {obs }}$ on the proton concentration (Fig. 1a). In the case of $[\mathrm{Mn}(\mathrm{dota})]^{2-}$, the fit led to reliable values for $k_{0}, k_{1}, k_{2}$ ( $k_{2}$ represents the spontaneous dissociation of the diprotonated complex) as well as to the stability constant of the dinuclear complex, $K_{\mathrm{MnLZn}}$, and the corresponding dissociation rate constant, $k_{3}$ (Table 2).

\section{Discussion}

The values of $k_{0}$ and $k_{1}$ are one order of magnitude higher for $[\mathrm{Mn}(\text { nota })]^{-}$than for $[\mathrm{Mn}(\text { dota })]^{2-}$, while the rate constants characterizing the metal-assisted dissociation, $k_{3}$, are very similar for both complexes. This difference in $k_{0}$ and $k_{1}$ accounts for the considerably faster dissociation of [Mn(nota) $]^{-}$as expressed by its shorter dissociation half-time calculated for various conditions (Table 2). At physiological $\mathrm{pH}$, the dissociation half-lives do not (or negligibly) depend on the $\mathrm{Zn}^{2+}$ concentration, and the contribution of the proton-assisted pathway, represented by $k_{1}$, is only $1 \%$. Therefore, under the simulated physiological conditions (pH 7.4 and $\left.c\left(\mathrm{Zn}^{2+}\right)=10^{-5} \mathrm{M}\right)$, the overall dissociation proceeds via the spontaneous dissociation pathway for both complexes, and the $\sim 15$-fold difference in the $t_{1 / 2}$ values is related to the different $k_{0}$ constants.

The mechanism of the spontaneous and the proton-assisted dissociation of $[\mathrm{Mn}(\text { nota })]^{-}$and $[\mathrm{Mn}(\text { dota })]^{2-}$ involves the same intermediates and reaction steps as that of their $\mathrm{Gd}^{3+}$ analogues. ${ }^{10,11}$ For the spontaneous dissociation of both complexes, the $\mathrm{Mn}^{2+}$ ion has to step out from the macrocyclic cavity forming an intermediate $\mathrm{ML}^{*}$ species $\left(k_{\mathrm{MnL}}\right.$, rate-determining step) in which one macrocyclic nitrogen atom is not any more bound to the $\mathrm{Mn}^{2+}$ ion. This step is followed by the rapid protonation of a nitrogen of the intermediate $\left(\mathrm{MnHL}^{*}\right)$ before the fast dissociation to free ligand and metal ion. In the proton-assisted pathway characterized by $k_{1}$, [Mn(nota) $]^{-}$becomes first protonated on one carboxylate group (HMnL). The carboxylates are known to be labile in this complex $^{40}$ and the protonation results in the decoordination of the carboxylic arm. Then, the proton transfer from the carboxylic group to a ring nitrogen atom causes an electrostatic repulsion which removes the $\mathrm{Mn}^{2+}$ ion from the macrocyclic cavity $\left(k_{\mathrm{MnHL}}\right.$, rate-determining step) and initiates the $\mathrm{MnHL}^{*}$ dissociation. The proton-assisted dissociation of [Mn(dota) $]^{2-}$ likely proceeds via an analogous mechanism, but involves two protonated intermediates, MnHL* and $\mathrm{MnH}_{2} \mathrm{~L}^{*}$, with one or two protonated and uncoordinated ring nitrogen atoms, respectively. The rate controlling step is always the formation of the intermediates $\left(\mathrm{MnL}^{*}, \mathrm{MnHL}^{*}\right.$ or $\mathrm{MnH}_{2} \mathrm{~L}^{*}$ ).

At higher acidity, the observed dissociation rates for both $[\mathrm{Mn} \text { (nota) }]^{-}$(Fig. 1b) and $[\mathrm{Mn}(\text { dota })]^{2-}$ (Fig. 2b) decrease with increasing $\mathrm{Zn}^{2+}$ concentration indicating the transitional formation of a slowly dissociating dinuclear $\mathrm{Mn}^{2+}-\mathrm{L}-\mathrm{Zn}^{2+}$ complex. This dinuclear complex competes with the protonated complexes. It dissociates more slowly than the protonated complexes, thus the overall dissociation rate is decreased. This decrease becomes more significant at higher proton concentration where the protonated (or diprotonated) species are more abundant while at low acidity the change in $k_{\mathrm{obs}}$ with increasing $\mathrm{Zn}^{2+}$ concentration is less important. Consequently, the dissociation half-times calculated for physiological $\mathrm{pH}$ do not vary with $\mathrm{Zn}^{2+}$ concentration (Table 2). The suppression of the dissociation rate with an excess of the exchanging metal ion has been previously observed for the transmetallation of $\mathrm{Gd}^{3+}$ complexes of open-chain (DTPA) ${ }^{13}$ 
or macrocyclic ligands (TETA, TRITA; Chart 1$)^{17}$ with $\mathrm{Eu}^{3+}$. The dissociation kinetic study on the divalent metal complex $[\mathrm{Cd} \text { (cydta) }]^{2-}$ (Chart 1) with exchanging $\mathrm{Pb}^{2+}$ or $\mathrm{Cu}^{2+}$ ions also revealed the same trend, ${ }^{41}$ and similarly, a dinuclear complex with the exchanging ion bound to the carboxylate pendant arm was proposed to account for this kinetic behaviour.

We can predict a higher tendency for dinuclear complex formation for the more negatively charged $[\mathrm{Mn}(\mathrm{dota})]^{2-}$ than for $[\mathrm{Mn}(\mathrm{Hdota})]^{-}$or $\left[\mathrm{Mn}\left(\mathrm{H}_{2} \mathrm{dota}\right)\right]^{0}$ with the protonated acetate pendant arm(s). Accordingly, the fitting of the $k_{\text {obs }}$ data showed that the zinc-assisted dissociation of both protonated complexes is negligible (vida supra). On the other hand, the dependence of $k_{\mathrm{obs}}$ on $\mathrm{Zn}^{2+}$ concentration is more pronounced for $[\mathrm{Mn}(\mathrm{dota})]^{2-}$ than for [Mn(nota) $]^{-}$, corresponding to the higher value of the dinuclear complex stability constant (Table 2). In addition to the higher negative charge, the increased flexibility of the acetate pendant arms in $[\mathrm{Mn}(\text { dota })]^{2-}$ also facilitates the approach of $\mathrm{Zn}^{2+}$ and contributes to the increased stability of the dinuclear complex. In contrast to the tightly packed structure of [Mn(nota) $]^{-}$, where all three carboxylates are coordinated to the metal ion $(\mathrm{CN}=6),{ }^{28}$ the octadentate ligand in $[\mathrm{Mn}(\mathrm{dota})]^{2-}$ might have non-coordinated acetate arms available for $\mathrm{Zn}^{2+}$ coordination. The crystal structure of [Mn(dota) $]^{2-}$ is not known. For the diprotonated [ $\left.\mathrm{Mn}\left(\mathrm{H}_{2} \mathrm{dota}\right)\right]$ complex, the solid-state structure has been reported; two protonated and non-coordinating acetate arms are present and the metal ion has $\mathrm{CN}=6 .{ }^{31} \mathrm{Six}-$ and seven-coordination are most common for poly(amino carboxylate) $\mathrm{Mn}^{2+}$ chelates. ${ }^{19,42}$ Only few examples of eight-coordination have been described, including the complex with a DOTA-tetraamide ligand, DOTAM (Chart 1), $[\mathrm{Mn}(\mathrm{dotam})]^{2+} \cdot{ }^{31}$ Even if all four carboxylates are coordinated to the metal ion in $[\mathrm{Mn}(\mathrm{dota})]^{2-}$, they will be more flexible and available for the formation of a dinuclear complex than those in $[\mathrm{Mn}(\text { nota })]^{-}$.

For the $\mathrm{Mn}^{2+}$ complex of the 15 -membered pyridine-macrocycle 15 -pyN $\mathrm{N}_{4},{ }^{19}$ both proton- $\left(k_{1}, k_{2}\right)$ and zinc-assisted $\left(k_{4}\right)$ dissociation pathways were found to be important, whereas the dissociation of the 15- $\mathrm{pyN}_{2} \mathrm{O}_{2}$ analogue was instantaneous and could not be studied under the same experimental conditions $(\mathrm{pH} 4.7-$ 6.0). The rate constants of $\left[\mathrm{Mn}\left(15-\mathrm{pyN}_{4}\right)\right]^{2+}$ are several orders of magnitude higher than those of $[\mathrm{Mn}(\text { nota })]^{-}$and $[\mathrm{Mn}(\text { dota })]^{2-}$, resulting in a much faster overall dissociation (Table 2). Several factors can account for this difference, including the presence of two inner-sphere water molecules in $\left[\mathrm{Mn}\left(15-\mathrm{pyN}_{4}\right)\right]^{2+}$, its lower thermodynamic stability and the more "open" structure of the azacrown-ether complexes that might result in different dissociation mechanisms.

For $\mathrm{Gd}^{3+}$ chelates, a large body of dissociation kinetic data has been reported which evidence a fundamentally different behavior for the complexes of open-chain, DTPA-derived, and macrocyclic, DOTA-derived ligands. For the dissociation of macrocyclic $\mathrm{Gd}^{3+}$ complexes, especially of $[\mathrm{Gd}(\mathrm{dota})]^{-}$, strongly acidic conditions had to be usually used because of their considerably high kinetic inertness, mainly related to their tight packing, preorganization and to the high rigidity of the 12-membered macrocycle. ${ }^{10,11,17}$ The dissociation was found independent of the exchanging metal ion concentration (when an exchanging metal ion was employed) under these highly acidic conditions, but also at higher $\mathrm{pHs}(\mathrm{pH}=$ $2-5),{ }^{9-11}$ and only $k_{0}$ and $k_{1}$ could be determined for [Gd(nota)] and $[\mathrm{Gd}(\mathrm{dota})]^{-}$(for $[\mathrm{Eu}(\mathrm{dota})]^{-}, k_{2}$ was also reported). ${ }^{11}$ The $k_{0}$ and $k_{1}$ values are comparable for [Gd(nota)] and [Mn(nota) $]^{-}$, and $[\mathrm{Mn}(\mathrm{nota})]^{-}$is even more inert under simulated physiological conditions (Table 2). This can likely be accounted for the smaller ionic radius of $\mathrm{Mn}^{2+}$ which suits well to the relatively small cavity of the triazacyclononane-based ligand contrary to the larger $\mathrm{Gd}^{3+}$ ion with an uncompleted coordination sphere. For the DOTA complexes, the dissociation half-time is several orders of magnitude longer for the $\mathrm{Gd}^{3+}$ analogue showing its extraordinary kinetic inertness (Table 2). The $\mathrm{Gd}^{3+}$ complexes formed with open-chain ligands are kinetically less inert than those with macrocycles and their dissociation proceeds mainly via metalassisted pathways. The overall dissociation rate of $[\mathrm{Gd}(\mathrm{dtpa})]^{2-}$ in the presence of $\mathrm{Zn}^{2+13}$ is in the same range as those for [Mn(nota)] or $[\mathrm{Mn}(\text { dota })]^{2-}$; however, it shows a much higher dependency on $\mathrm{Zn}^{2+}$ concentration even at physiological conditions.

The high kinetic inertness of $[\mathrm{Mn}(\text { dota })]^{2-}$ indicates a promising direction in designing ligands for stable $\mathrm{Mn}^{2+}$ complexation. The modification of the DOTA scaffold by changing and/or removing some pendant arms can result in a free site for water coordination in a thermodynamically and kinetically stable $\mathrm{Mn}^{2+}$ complex. Recently, a relaxivity of $r_{1}=6.2 \mathrm{mM}^{-1} \mathrm{~s}^{-1}\left(20 \mathrm{MHz}, 37^{\circ} \mathrm{C}\right)$ has been reported for the $\mathrm{Mn}^{2+}$ complex of 1,7-DO2A ${ }^{31}$ (Chart 1) which suggests the presence of one inner-sphere water in the complex.

\section{Conclusion}

The dissociation kinetic study of $[\mathrm{Mn}(\text { dota })]^{2-}$ and $[\mathrm{Mn} \text { (nota) }]^{-}$ revealed unexpectedly high kinetic inertness, disproving that $\mathrm{Mn}^{2+}$ complexes are all kinetically labile. In addition to the high thermodynamic complex stability, the saturation of the coordination sphere of $\mathrm{Mn}^{2+}$ exclusively by the ligand donor atoms (no innersphere water) can also contribute to this kinetic inertness. The dissociation is strongly $\mathrm{pH}$-dependent and proceeds $\sim 15$ times faster for $[\mathrm{Mn}(\mathrm{nota})]^{-}$than for $[\mathrm{Mn}(\mathrm{dota})]^{2-}$, under both experimental and physiologically relevant conditions. This difference results from the higher rate constants calculated for the spontaneous and the proton-assisted dissociation, $k_{0}$ and $k_{1}$, respectively. In the transmetallation with $\mathrm{Zn}^{2+}$, the exchanging metal ion suppresses its own rate of exchange due to the formation of a stable dinuclear $\mathrm{Mn}^{2+}-\mathrm{L}-\mathrm{Zn}^{2+}$ complex which dissociates more slowly than the protonated species. This phenomenon is particularly significant at low pHs where the protonated complexes contribute more actively to the overall dissociation. The effect of the dinuclear complex formation is more significant for $[\mathrm{Mn}(\text { dota })]^{2-}$; it is also expressed by a $\sim 20$-times higher value of the stability constant of its $\mathrm{Mn}^{2+}-\mathrm{L}-\mathrm{Zn}^{2+}$ complex. Our results suggest that for both complexes the spontaneous dissociation pathway prevails under physiologically relevant $\mathrm{H}^{+}$and $\mathrm{Zn}^{2+}$ concentration. Given the high kinetic inertness of $[\mathrm{Mn}(\mathrm{dota})]^{2}$, DOTA-type ligands are prime candidates for the development of $\mathrm{Mn}^{2+}$-based MRI probes.

\section{Acknowledgements}

We thank Dr J. Havlíčková for the protonation/stability constant measurements. Support from the Grant Agency of the Academy of Science of the Czech Republic (No. KAN201110651) and the Long-Term Research Plan of the Ministry of Education of the Czech Republic (No. MSM0021620857) is acknowledged. B. Drahoš acknowledges the $\mathrm{PhD}$ grant of the RFR program 
of the French Ministry of Education and Research. The work was carried out in the frame of COST D38 (MŠMT OC 179) and the Grant Agency of the Czech Republic (No. P207/11/1437).

\section{Notes and references}

1 E. Terreno, D. D. Castelli, A. Viale and S. Aime, Chem. Rev., 2010, 110, 3019-3042.

2 Future Med. Chem., 2010, 2, 305-531. The issue No. 3 is dedicated to "Molecular Probes in Optical and Magnetic Resonance Imaging".

3 S. Aime, D. D. Castelli, S. G. Crich, E. Gianolio and E. Terreno, Acc. Chem. Res., 2010, 42, 822-831.

4 E. Tóth and A. E. Merbach, The Chemistry of Contrast Agents in Medical Magnetic Resonance Imaging, John Wiley \& Sons, Chichester, 2001.

5 P. Hermann, J. Kotek, V. Kubíček and I. Lukeš, Dalton Trans., 2008, 3027-3047.

6 J. M. Ideé, M. Port, C. Robic, C. Medina, M. Sabatou and C. Corot, J. Magn. Reson. Imaging, 2009, 30, 1249-1258.

7 E. Brücher and A. D. Sherry, Stability and Toxicity of Contrast Agents, in The Chemistry of Contrast Agents in Medical Magnetic Resonance Imaging, É. Tóth and A. E. Merbach ed., Wiley, Chichester, 2001, pp. $243-280$.

8 A. D. Sherry, P. Caravan and R. E. Lenkinski, J. Magn. Reson. Imaging, 2009, 30, 1240-1248.

9 X. Wang, T. Jin, V. Comblin, A. Lopez-Mut, E. Merciny and J. F. Desreux, Inorg. Chem., 1992, 31, 1095-1099.

10 E. Brücher and A. D. Sherry, Inorg. Chem., 1990, 29, 1555-1559.

11 É. Tóth, E. Brücher, I. Lázár and I. Tóth, Inorg. Chem., 1994, 33, 4070-4076.

12 P. Caravan, J. J. Ellison, T. J. McMurry and R. B. Lauffer, Chem. Rev., 1999, 99, 2293-2352.

13 L. Sarka, L. Burai and E. Brücher, Chem. Eur. J., 2000, 6, 719724.

14 J. Kotek, F. K. Kálmán, P. Hermann, E. Brucher, K. Binnemans and I. Lukeš, Eur. J. Inorg. Chem., 2006, 1976-1986.

15 Z. Jászberényi, I. Bányai, E. Brücher, R. Király, K. Hideg and T. Kálai, Dalton Trans., 2006, 1082-1091.

16 Z. Baranyai, Z. Pálinkás, F. Uggeri and E. Brücher, Eur. J. Inorg. Chem., 2010, 1948-1956.

17 E. Balogh, R. Tripier, R. Ruloff and É. Tóth, Dalton Trans., 2005, $1058-1065$.

18 V. Kubíček and É. Tóth, Adv. Inorg. Chem., 2009, 61, 63-129.

19 B. Drahoš, J. Kotek, P. Hermann, I. Lukeš and É. Tóth, Inorg. Chem., 2010, 49, 3224-3238.

20 T. Murakami, R. L. Baron, M. S. Peterson, J. H. III. Oliver, P. L. Davis, B. S. Confer and M. P. Federle, Radiology, 1996, 200, 69-77.

21 S. Aime, P. L. Anelli, M. Botta, M. Brocchetta, S. Canton, F. Fedeli, E. Gianolio and E. Terreno, JBIC, J. Biol. Inorg. Chem., 2002, 7, 58-67.
22 J. S. Troughton, M. T. Greenfield, J. M. Greenwood, S. Dumas, A. J. Wiethoff, J. Wang, M. Spiller, T. J. McMurry and P. Caravan, Inorg. Chem., 2004, 43, 6313-6323.

23 E. Balogh, Z. He, W. Hsieh, S. Liu and É. Tóth, Inorg. Chem., 2007, 46, 238-250

24 NMR Biomed., 2004, 17, 527-634. The issue No. 8 is dedicated to the "Manganese Enhanced Magnetic Resonance Imaging (MEMRI)".

25 B. Gallez, C. Baudelet and M. Geurts, Magn. Reson. Imaging, 1998, 16, 1211-1215.

26 S. M. Rocklage, W. P. Cacheris, S. C. Quay, F. E. Hahn and K. N. Raymond, Inorg. Chem., 1989, 28, 477-485.

27 C. F. G. C. Geraldes, A. D. Sherry, R. D. III. Brown and S. H. Koenig, Magn. Reson. Med., 1986, 3, 242-250.

28 K. Wieghardt, U. Bossek, P. Chaudhuri, W. Herrmann, B. C. Menke and J. Weiss, Inorg. Chem., 1982, 21, 4308-4314.

29 Y. Fukuda, M. Hirota, M. Kon-no, A. Nakao and K. Umezawa, Inorg. Chim. Acta, 2002, 339, 322-326.

30 A. Bianchi, L. Calabi, C. Giorgi, P. Losi, P. Mariani, D. Palano, P. Paoli, P. Rossi and B. Valtancoli, J. Chem. Soc., Dalton Trans., 2001, 917-922.

31 S. Wang and T. D. Westmoreland, Inorg. Chem., 2009, 48, 719-728.

32 Scientist for Windows, Version 2.0, Micromath Inc., Salt Like City, UT, 1995.

33 (a) M. Kývala and I. Lukeš, International Conference Chemometrics '95, Pardubice, Czech Republic, 1995, p. 63; (b) M. Kývala, P. Lubal and I. Lukeš, IX. Spanish-Italian and Mediterranean Congress on Thermodynamics of Metal Complexes (SIMEC 98), Girona, Spain, 1998.

34 (a) A. E. Martell and R. M. Smith, Critical Stability Constants, Vols. 1-6, Plenum Press, New York, 1974-1989; (b) NIST Standard Reference Database 46 (Critically Selected Stability Constants of Metal Complexes), Version 7.0, 2003; (c) C. F. Jr., Baes and R. E. Mesmer, The Hydrolysis of Cations, Wiley, New York, 1976.

35 (a) P. Táborský, P. Lubal, J. Havel, J. Kotek, J. Rudovský, P. Hermann and I. Lukeš, Collect. Czech. Chem. Commun., 2005, 70, 1909-1942; (b) M. Försterová, I. Svobodová, P. Lubal, P. Táborský, J. Kotek, P. Hermann and I. Lukeš, Dalton Trans., 2007, 535-549.

36 S. Cortes, E. Brücher, C. F. G. C. Geraldes and A. D. Sherry, Inorg. Chem., 1990, 29, 5-9.

37 H. Hama and S. Takamoto, Nippon Kugaku Kuishi, 1975, 1182-1185. CAN: 83:121751, CODEN: NKAKB8, ISSN: 0369-4577.

38 G. Anderegg, F. Arnaud-Neu, R. Delgado, J. Felcman and K. Popov, Pure Appl. Chem., 2005, 77, 1445-1495.

39 A. Bianchi, L. Calabi, C. Giorgi, P. Losi, P. Mariani, P. Paoli, P. Rossi, B. Valtancoli and M. Virtuani, J. Chem. Soc., Dalton Trans., 2000, 697-705.

40 C. F. G. C. Geraldes, M. C. Alpoim, M. P. M. Marques, A. D. Sherry and M. Singh, Inorg. Chem., 1985, 24, 3876-3881.

41 G. F. Smith and D. W. Margerum, Inorg. Chem., 1969, 8, 135-138.

42 S. H. Koenig, C. Baglin, R. D. III. Brown and C. F. Brewer, Magn. Reson. Med., 1984, 1, 496-501. 